\title{
SARAH HEALY
}

\section{EVALUATING SPACES OF PEDAGOGIC AFFECT}

\section{INTRODUCTION}

I have a teenaged son. A few months ago he came home announcing that he wanted to go to a different school. Then, after a school tour he back-flipped saying: "Mum, I can't go to that school." When I inquired why, he said, "I don't like the feel of it". And I got it. Truth be known, I didn't like the feel of it either. So what was it about that school's environment that affected my son in such a way? Was it the cold? The smell? The green lino? The serious demeanor of the students? The old style classrooms? The greasy humidity of the canteen? The institutional grey of the music block? The clanging school bell that made us all jump? Most likely it was the complex interplay (or intra-play) of all these things and more that made the school feel the way it did.

This brief encounter raises certain questions: What makes a learning space attract rather than repel? And lure somebody in? And invite someone into a pedagogic experience? How does it acquire the hallmarks of a pedagogic masterpiece? And how do we investigate this when its primary concerns are often ephemeral and non-representational phenomena like affect and affective atmospheres? And how will investigating this grow our understandings of learning spaces, pedagogies, their affects, and what they do? And why is this important?

These are tricky questions that elude a simple response. At the same time it is questions like these that have the capacity to catalyse into new knowledge and practice, but only for those brave or foolhardy enough to wrestle with them. This final chapter is a brave (but hopefully not too foolhardy) proposition to do just this. The result is the development of a trajectory for future pedagogic and learning space evaluation that departs from pervasive social constructivist, cognitivist and behaviouralist approaches to education. As an exemplar of what this may look like I present a snapshot of a multiple-case study $\mathrm{PhD}$ investigating pedagogic affect across heterogeneous contexts such as sports clubs, sculpture walks, historic sites, museums and playgrounds. Key concepts such as pedagogical force, scenes of pedagogical address, and the materiality of affect are put to work through a practical engagement with broadly conceived spaces of learning that move beyond bounded notions of learning spaces and their pedagogies. The notion of 'beyond' itself becomes a thread running through much of this chapter, with concepts such as more-than-human, more-than-representational, beyond anthropocentric pedagogy, and beyond the pedagogic encounter underpinning its ontoepistemology. 


\section{CONTEXT}

Beyond a $21^{\text {st }}$ century 'grammar of schooling'

Learning spaces are gaining increasing attention with associated notions of 'innovation', ' $21^{\text {st }}$ century learning' and the perceived need to address outmoded industrial modes of schooling proliferating in public and policy discourse. This is reflected in the titles of Australian government and OECD documents such as: Pedagogy and Space: Transforming Learning Through Innovation (DEECD, 2009), $21^{\text {st }}$ Century Learning: Research, Innovation and Policy (OECD, 2008), and Innovative Learning Environments (OECD, 2013). Accompanying ideas of $21^{\text {st }}$ century innovation and learning is the widely circulated proposition that 'schools are preparing students for jobs that don't exist yet'. The connotations are that, to meet the future focussed needs of the $21^{\text {st }}$ century learner, new (innovative) pedagogies and learning spaces need to be developed that foster competencies such as: creative, innovative and critical thinking; problem solving; decision-making; learning to learn/metacognition; communication; collaboration; information and ICT literacy; global and local citizenship; personal and social responsibility (http://www.atc21s.org).

Yet, with the exception of information and ICT literacy, history's plentiful examples of learning space innovation show that contemporary 'innovative learning environments' (ILEs) and their corresponding pedagogies are not as innovative as the name implies. The following are all historical examples of pedagogical and learning space innovation: traditional Australian Aboriginal learning on country (at least 50,000 years of continuous culture), The Idiot Teacher and Prestolee (1918-1953), Mabel Chrystie's First Street School (Founded 1964), Italy's Reggio Emilia movement (Post WWII), and Steiner schooling (1919 onwards). As Hattie (2008) aptly observes, there has been no shortage of innovation in education, just a shortage of ongoing demand for innovative programs (p. 2). Indeed, the very notion of innovation in education is problematic (Blackmore, Bateman, O’Mara, Loughlin, \& Aranda, 2010; Resnick, Spillane, Goldman, \& Rangel, 2010). One reason is that sedimentations of social, spatial, material, relational and temporal pedagogic assemblages create a 'grammar of schooling' (Tyack \& Tobin, 1994) and an associated 'grammar of pedagogy' that is resistant to change. Pedagogic routines and practices that have long existed, come to constitute perceptions of what 'real' pedagogy is, and what it should be - rematerialising in pedagogic routines and practices to come (Lenz-Taguchi, 2010).

The current policy and research focus on ILEs and ILE related discourse can be seen to be creating a new grammar of schooling by promoting one incarnation of learning space innovation while distracting attention from the many 'innovations' that have gone before and those presently happening. It positions schools and ILE discourse at the centre, pushing more broadly conceived pedagogic spaces to the periphery. This creates blind spots in the learning space evaluation field, limiting the possibilities that may arise. In order to bring such blind spots into view, there is a need to move beyond bounded notions of the ILE by taking a more gestalt approach to learning space research (Healy, Grant, Villafrance, \& Yang, 2015). Such an approach is defined as analysing "the totality of a particular situation and its constituent parts in relation to one another (Wollants, 2008) where 'all contact is creative adjustment of the organism and environment' (Perls, Hefferline and 
Goodman, 1951, p.7)" (Harris, 2010, p. 19). For learning space evaluation this means acknowledging that learning is not confined to school and school-based pedagogies but emerges through heterogeneous pedagogic encounters (human and non-human) that occur in a variety of settings.

\section{Towards the affective}

How pedagogic affect influences the effectiveness of learning spaces is also an important consideration for future learning space evaluation. The role of the affective dimension of learning has been gaining increasing attention in educational circles. This is reflected in the identification of "learners' motivations and importance of emotions" as one of seven learning principles that underpin the OECD's recently developed ILE framework (CERI, 2015). Current and emerging curriculums across Australia are also recognising the value of Social and Emotional Learning (SEL). For example, within Australia the Victorian curriculum aims to develop students' personal/emotional and social/relational capacities through one of four cross-curricular capabilities, 'The Personal and Social Capability' (VCAA, n.d.). This is supported by related literature on SEL that shows evidence of a range of personal, social, behavioural and academic benefits from effective SEL programs in schools (Farrelly, Forster, \& Smith, 2014).

However, the framing of emotions in the OECD's ILE framework, the Victorian curriculum, and much of educational literature uses psychology-based definitions of emotion and affect. Correspondingly, SEL pedagogies remain located in cognitivist and social constructivist domains. In contrast, I argue the need for the learning space evaluation field to consider the potential of alternate approaches to investigating the role of affective pedagogic spaces. The proposed research trajectory presented adopts an approach that leverages off Deleuze/Guatarrian understandings of affect, generating possibilities for analysing affective pedagogic spaces in terms of intensities, atmospheres, forces, flows, and becomings that materialise in embodied responses and changes to what a body has the capacity to do. This approach is informed by the growing body of interdisciplinary literature on affect that has led to the so-called 'affective turn' in social theory (Clough \& Halley, 2007).

\section{Towards the spatial}

The 'affective turn' follows a similarly interdisciplinary 'spatial turn' that has led to the identification of what Fisher (2004) describes as "a deep spatial silence" at work in schools (p. 36). A subsequent spatial project has been to restore a spatial consciousness to the temporal and social by highlighting how space is integral to understanding these concepts. The resulting "three-sided sensibility of spatialityhistoricality-sociality" (Soja, 1996, p. 3) has productively led to diverse critical analyses of socio-spatial practices in the education field (Gulson \& Symes, 2007; McGregor, 2004a). The focus of spatially orientated research is determined by how space is used as a conceptual tool, which in turn is determined by how space itself has been framed. The framing of space for this proposed research trajectory is primarily, but not exclusively, informed by post-structuralist and new materialist conceptions of space (for example: Soja's (1996) notion of the third space as a site of radical openness and Barad's (2007) understanding of matter and the material). 
In this way I am proposing a research trajectory for evaluating learning spaces and pedagogies that aligns with the educational contexts of both the affective and the spatial.

\section{Towards the more-than-human}

The rise in interest in affect and space in education is underscored by a move towards posthuman (or more-than-human) research approaches drawing on the sociomaterial (Fenwick, Edwards, \& Sawchuk, 2011), new materialisms (Coole \& Frost, 2010; Fox \& Alldred, 2015), and material feminisms (Alaimo \& Hekman, 2008). A common thread running through these interrelated paradigms is the understanding of the material and social as being inextricably enmeshed. The human is no longer privileged and the material not relegated to the background. This sets the premise for rethinking affective and spatial relations creating the conditions for realist vs social constructivist debates to shift to 'emergent interplay', rejecting mind/body, social/material and material/discursive binaries (Jackson \& Mazzei, 2012, p. 114). This is to "release and redirect the forces now locked up in such binaries by addressing them ... as complex, moving webs of inter-relationalities" (Ellsworth, 2005, p.3) and is useful because it fosters dynamic re-imaginings of educational practices that are not limited to dominant instrumental approaches to pedagogy (Lenz Taguchi, 2011).

\section{Towards more-than-human pedagogues and pedagogies}

Barad (2007) notes that in a posthuman sense material and human agencies are mutually formative and emergent: agency is not possessed but distributed across the human and non-human as an emergent enactment (Jackson \& Mazzei, 2012, p. 117). If this agential logic is applied to pedagogy it follows that material and human pedagogies are mutually formative and emergent: pedagogy is not possessed but distributed across the human and non-human as an emergent enactment. Human teachers can no longer be assumed to be the primary pedagogue in all situations - rather pedagogy emerges out of mutually constitutive assemblages of bodies, materials, media, affects, atmospheres, and space. Therefore a focus of this proposed research trajectory is how the complex choreography of these inter-relational and intra-relational components create what Ellsworth (2005) refers to as 'the force of pedagogy' (p. 35) and what I call pedagogic affect.

\section{MOVING FROM AN ABSTRACT TRAJECTORY INTO CONCRETE RESEARCH}

The affective, spatial and more-than-human contexts presented help establish the need for research that evaluates learning spaces to transcend limited conceptions of pedagogy and learning spaces by accounting for "how life takes shape and gains expression in shared experiences, everyday routines, fleeting encounters, embodied movements, precognitive triggers, affective intensities, enduring urges, unexceptional interactions and sensuous dispositions" (Lorimer, 2005, p. 84). Doing so addresses a blindness towards spatial (Fisher, 2004), non-linguistic (Ellsworth, 2005), and material (Fenwick et al., 2011) influences on educational 
practice while affording a more nuanced understanding of the mutual becomings of built and naturally occurring pedagogic spaces, inhabitants, and affective flows.

At the same time certain questions emerge: how does a trajectory that seeks to move beyond bounded notions of the learning environment, the pedagogue and pedagogy manifest in evidence-based research? And, what does an approach that accounts for the embodied experiences of the affective, spatial, relational and material look like? The following $\mathrm{PhD}$ research design provides a concrete example of how such a study may manifest, showing one of many possibilities for such a research trajectory.

\section{An exemplar: PhD research into heterogeneous spaces of pedagogic affect}

The exemplar I present is a $\mathrm{PhD}$ study about how pedagogic affect works across diverse learning contexts. It takes the form of a multiple-case study and is a direct example of what research following a spatial, affective, material and relational trajectory might look like. The precedent for the research is set by literature pertaining to pedagogic affect (Baker, 2008; Ellsworth, 2005; Hickey-Moody \& Crowley, 2010; Hickey-Moody, 2013b; Kraftl, 2015; Watkins, 2006; Zembylas, 2007b) that shows cause for evaluating how affect and affective learning spaces can be designed to create 'pedagogical masterpieces' (Ellsworth, 2005). Drawing on a range of theorists that align with a non-representational approach, the $\mathrm{PhD}$ research puts concepts of affect and space to work. It adopts a Deleuzian understanding of affect while also referencing Ellsworth's (2005) Places of Learning: Media, Architecture, Pedagogy. Although Ellsworth's work pre-dates non-representation theory and does not draw on Deleuze, her work embodies the spirit of what the $\mathrm{PhD}$ research is trying to achieve and of what future pedagogic and learning space evaluation needs to capture.

\section{What does the literature says about heterogeneous spaces of pedagogic affect?}

A literature search around the key constructs related to the geographies of pedagogic affect reveals little engagement with how pedagogic affect emerges across heterogeneous spaces of learning. Although there are studies investigating broadly conceived learning spaces, there is a general absence of comparative studies looking at pedagogic affect across a variety of different contexts. There is, however, a large volume of educational literature concerning the core concepts of space, pedagogy and affect. The following (very brief) review of the literature looks at where these concepts converge in interconnecting arenas of 'space and pedagogy', 'space and affect', and 'pedagogic affect', culminating in a comment about embodiment and affect.

Space and pedagogy.

Historically, learning spaces have been perceived as the built environment, operating as a backdrop to the teaching and learning that takes place within. As such they were treated as "a material location in which education research is located" (Leander, Phillips, Taylor, Nespor, \& Lewis, 2010, p. 331). Now, thanks 
in part to theoretical developments by the geographers, learning spaces are no longer taken as inert containers of learning but are understood as products of mutually constitutive socio-spatial dialectics: "a dynamic multiplicity that is constantly being enacted by simultaneous practices-so-far" (Fenwick et al., 2011, p.11). They are widely considered as physical, conceptual and/or virtual spaces of learning that can be seen as networks, systems or ecologies, hence the related term 'learning environment.' It is within this Lefebvrian (1991) conception of learning spaces that the links between inhabitation of physical learning spaces and their associated pedagogies are explored in this literature review.

With the exception of work by Byers and Imms (2016), researchers from a range of methodological backgrounds have argued there is no direct causal relationship between learning spaces and learning outcomes or teacher change (Blackmore et al., 2011; Hattie, 2008; Mulcahy, Cleveland \& Aberton, 2015). However, it has been shown that "learning spaces can produce conditions and mediate relationships that can improve student learning" (Blackmore et al., 2011, p. 4), and further claims have been made regarding a critical link between the material learning space and student learning (OWP/P Architects, VS Furniture \& Bruce Mau Design, 2010). Yet Blackmore et al.'s (2011) comprehensive literature review of learning spaces and student outcomes found little empirical research on how school spaces are used pedagogically to improve learning. Since then, further school-based studies have been conducted that address this gap and improve understandings of the relationships between spaces and pedagogies, for example: Deed and Lesko (2015); Dovey and Fisher (2014); Mulcahy et al. (2015); Saltmarsh, Chapman, Campbell, and Drew (2015); and Woolner, Clark, Laing, Thomas, and Tiplady (2014). Interestingly, these studies show that the inhabitation of newly designed learning spaces does not necessarily lead to progressive change in pedagogical practice. To the contrary, Dovey and Fisher's (2014) study found new school designs can in fact camouflage conservative pedagogies. The complex ecology of learning spaces would suggest that looking for simple causal effects between pedagogy and space is misguided. Rather, seeking to understand the meshwork (Ingold, 2011), of socio-material inter- and intra-relations at work in learning spaces may be a more generative path. Even so, a case has been made for quasiexperimental research seeking correlations between space, pedagogy and student outcomes (Byers, Imms, \& Hartnell-Young, 2014).

While the extent to which space influences teaching and learning is contested, it is widely accepted that pedagogy itself plays a crucial role in student outcomes. According to Hattie's (2008) synthesis of over 800 meta-analyses, what the teacher does and does not do has the single greatest effect on student learning outcomes in schools. While this is a strong, empirically backed statement, it still begs the question: Is it all about the pedagogue, the pedagogy or the pedagogic assemblage? And who/what is the pedagogue anyway? If we adopt a relational materialist view of pedagogy we can begin to understand it not as a thing that is possessed and performed by (human) teachers, but as a material process distributed across human actors and material actants. This recognises the mutually formative nature of human/material pedagogies while expanding our pedagogic vernacular to encompass the likes of architecture, art, exhibitions, playground design, sport, media, music and performance. From this position anthropocentric (human centred) and logocentric (language centred) pedagogical approaches, commonly associated with behaviouralist, cognitivist and social constructivist pedagogies 
(Lenz Taguchi, 2011, p. 210) are opened up to more-than-human and more-thanrepresentational possibilities. A relational materialist understanding exposes how pedagogies and spaces are intertwined while creating room for broader conceptions of learning spaces and their pedagogies that extend beyond school.

It is worth noting there is a related body of educational literature concerned with heterogeneous spaces, places and to varying degrees the relational materialities of pedagogy. These studies reflect a rich landscape of pedagogy resulting in valuable outcomes. Some invite a change of heart towards children and their spaces of inhabitation (Burke, 2008), others show how parents can learn collaboratively with their very young children in the public space of an art museum (Ross, Hancock, \& Bagnall, 2004), and others critically examine space-power relationships highlighting teachers' seen and unseen pedagogies at work through spatial practices (McGregor, 2004b). All draw our attention to space, place and the materiality of the learning in significant ways while starting to unpack what McLeod (2014) identifies as the "multilayered, iterative relationship" (p. 134) between pedagogy and learning space design. These studies show the potential of looking to heterogeneous learning spaces for better understandings of how space may be used pedagogically to improve learning.

Yet, because of a focus on the development of individuals (Fenwick et al., 2011, pp. 5-6) even the most materially orientated of these studies can also be seen to examine educational practices that are underpinned by instrumental, human centred, language centred pedagogies. The problem with this being that by putting humans at the centre blinds us to the material and relational forces in the pedagogic event, leading to an overemphasis on language as a way to understand pedagogic processes (Lenz Taguchi, 2011, p. 212). An alternative approach is to see pedagogy (and therefore learning) as emerging from distributed networks and assemblages. This relocates pedagogy and learning from within human individuals to a liminal space of intra-activity that occurs in-between bodies and material artifacts, affects, atmospheres and spaces (Lenz Taguchi, 2011, p. 221). This way of thinking about pedagogy leads to the notion of 'the pedagogic encounter' as being central to thinking and learning. This means learning can be seen as emerging from encounter/s between bodies (non-human and human), material artifacts, affects, atmospheres and spaces. Paying specific attention to the encounter is important because it affords an understanding of "the stability of form amid the dynamism of formation" (Anderson \& Harrison, 2012, p. 19). 
Space and affect. Affect and space can be understood as inter-related and coconstitutive. Affects do not simply reside inside bodies or things but have an autonomy that allows them to flow between bodies and things. In this sense affects make spaces (Bissell, 2012, p. 81), while spaces configure affects. That is, spaces are affected and affect, are conditioned and condition. An excellent example of how concepts of space and affect are generatively worked together is Bissell's (2012) investigation into the uncertain geographies of pain. His emphasis on the temporal and spatial characteristics of affect allowed him to explore the affective topologies of pain revealing the conditions for different affects to emerge, changing "the realm of possibility for the body in pain" (Bissell, 2012, p. 82). Likewise studies concerned with the affective topologies of pedagogy may benefit from the adoption of Bissell's approach, potentially 'changing the realm of possibility for the body' in education.

Pedagogic affect. Pedagogic affect is a relatively recent area of educational interest. With the potential for affect to reconfigure education in significant ways not yet fully realised, it can arguably be considered "an emerging point of intervention and analysis" (Hickey-Moody \& Crowley, 2010, p. 401). Pedagogic affect can be understood simultaneously as material entity and a mode of cognition, working as an "interleaving of affect and cognition" (Ellsworth cited by HickeyMoody \& Crowley, 2010, p. 403). This framing of affect works in a two-fold way. Not only does it break down (problematic) affective/cognitive binary in education but it also provides an entry point for different accounts of affect theory to engage with each other. Defining pedagogy as the interleaving of affect and cognition opens the door for philosophical approaches to affective pedagogies to (re)engage with the likes of social psychology and occupy an interdisciplinary space, not limited by theoretical affiliations.

Classroom practice has been the focus of much educational literature related to pedagogic affect (see for example: Albrect-Crane \& Daryl Slack, 2003; Mulcahy, 2012; Mulcahy et al., 2015; Skattebol, 2010; Walshaw, 2012; Watkins 2006, 2011; Youdell \& Armstrong, 2011; Zembylas, 2007). This is understandable given classrooms are the main spaces of learning in contemporary schooling, however a narrow focus does not account for the range of affect-laden pedagogic phenomena that may be encountered. Where the literature ventures into other domains, there seems to be limited exploration into how pedagogic affect plays out comparatively across different contexts. While museums are increasingly being recognised for their affective pedagogic capacities (Baker, 2008; Ellsworth, 2005; Mulcahy, in press) there is still an absence of literature exploring the comparative affects arising from pedagogic encounters occurring across a variety of pedagogic vernaculars such as performance, design, art, music, sport, architecture and film.

Embodiment and affect. Zembylas (2007b) argues the mind/body Cartesian split has led to ignoring bodies and affect in education. However affective embodied learning is known as an integral component of the emergent learner: "The lived experience of learning is always affective; whether learning how to conjugate a verb in a classroom (Watkins 2012) or how to dance in a nightclub (Henriques 2010), our bodies and their affective registers are the flesh of pedagogy" (HickeyMoody, 2013b, p. 126). Further, bodies have affective responses to the spaces they inhabit, they simultaneously affect and are affected by those spaces. Mulcahy adds, 
"bodies are a chief site of securing the circulation of affects" finding affective pedagogic encounters in the museum have the power to engender learning that 'sticks' with the learner (Mulcahy, in press). Along similar lines, Zembylas points out that a Deleuzian conceptualisation of bodies and affects has the power to transform pedagogy into something "that engages students' and teachers' bodies and affects in a 'love affair' with bodies of knowledge" (Zembylas, 2007b, p. 28).

Summary of literature. A historical neglect of the affective and spatial in education has created room for further research into how affective space may be pedagogically worked to improve learning. The literature suggests affect is key to understanding how the spatial, material, relational and pedagogical work in concert yet reveals limited investigations into how this plays out comparatively across different heterogeneous learning spaces. The findings from previous research build a case for investigating heterogeneous learning spaces (Ellsworth, 2005; HickeyMoody, 2013b) while arguing the need for "more theoretically diverse considerations of pedagogy in education" (Hickey-Moody, 2013b, p. 121). This reiterates the need for research that adopts a relational, more-than-human, and more-than-linguistic understanding of the pedagogue and associated pedagogies while recognising the affective, spatial, and material as modes of pedagogical address (Ellsworth, 2005; Hickey-Moody, 2013b). It also shows a need for research that accounts for how learners are implicated in affective pedagogies of space, with the literature suggesting that this might be achieved by considering the pedagogic encounter as an intricate spatial, material, relational and affective assemblage.

\section{How does this shape the design of research into heterogeneous spaces of} pedagogic affect?

It can be surmised that the literature discussed not only supports a research trajectory for learning spaces and their pedagogies that accounts for the affective, spatial, material and relational but also offers many possible entry points for designing research to this end. Returning our attention to the exemplar PhD study, we will now look at how research addressing these concerns may take shape. To be consistent with its onto-epistomology, such research emphasises relational processes, and therefore requires process driven research questions about how particular phenomena work in a given context and to what effect? This means looking beyond what does and doesn't work to investigating how it works (or doesn't work) and with what consequences. The resulting research questions for the exemplar $\mathrm{PhD}$ study are: How does pedagogic affect work across heterogeneous learning contexts? And, for whom?

Examining these research questions while highlighting the dynamic interrelationalities at play requires a methodology and method that are at once experimental and robust. The following section outlines the development of an experimentally robust methodology and method that may be utilised to do this in the context of the exemplar PhD study.

Methodology 
Non-representationalism. The research design itself is underpinned by a nonrepresentational approach that is characteristically experimental in nature. Having been recognised for its potential for studying the likes of affect, atmospheres, performativity, relationality and spatiality, non-representationalism aligns well with this type of study. The corresponding theoretical framework sits under the umbrella of non-representational theory, a theory that can essentially be understood as a synthesis of diverse but inter-related theories from fields that include (but are not limited to) cultural geography, French philosophy, new material feminism, critical theory, and affect theory. It is described as "a hybrid genre for a hybrid world" (Vannini, 2015, p. 3) and it "seek[s] to engage and present (rather than represent)" (Cadman, 2009, p. 1). Non-representational theory can come in many guises depending on the theories chosen to work with. The two theories tied together to create the particular non-representational approach for this research are: spatial theory and a Deleuzian inspired theory of affect.

Multiple-case study methodology. To achieve the aim of showing how the phenomenon of pedagogic affect works across heterogeneous pedagogic assemblages, and how it manifests through different vernaculars such as architecture, performance, art, sport, and museum design a multiple-case study design, primarily using Yin's (2014) approach to designing case studies, has been adopted. The case is that of pedagogic affect and will be studied across four heterogeneous contexts. Replication logic is used and a holistic approach to the research design is used, resulting in a single unit of analysis (the affective pedagogic encounter). The multiple-case study as a methodology works well with non-representational research because it does not stipulate methods and is flexible enough to accommodate its experimental nature whilst providing a sound methodological framework to work within.

Selection of research contexts. The research contexts have been purposefully selected to form a collection of affect laden heterogeneous sites that express pedagogic intent through a variety of pedagogic vernaculars (see Table 1.). In addition, each site has sufficient supporting documentary data available to the public suitable for documentary analysis. In order to fulfil the requirement of heterogeneity the research contexts are geographically and pedagogically diverse. Their locations include Victoria, New South Wales, Tasmania and New Zealand. The pedagogies associated with the sites are equally diverse. What they have in common is their capacity to affect. Yet, the way this affective capacity plays out across different sites remains to be seen. The pedagogic affect of a high intensity Taekwondo competition will likely be very different from the airy atmosphere associated with certain historic sites. Equally contrasting are the pedagogic mediums associated with each context. Even the same pedagogic medium (such as the built environment) will function differently across contexts. For example, the sports stadium that typically houses a Taekwondo competition operates very differently to a curated outdoor sculpture installation. 
Table 1. Research contexts and participants

\begin{tabular}{|c|c|c|c|c|}
\hline $\begin{array}{l}\text { Context } \\
\text { /site }\end{array}$ & Location & Participants & $\begin{array}{l}\text { Pedagogic } \\
\text { intent }\end{array}$ & $\begin{array}{l}\text { Pedagogic } \\
\text { medium }\end{array}$ \\
\hline $\begin{array}{l}\text { Adventure } \\
\text { Playground }\end{array}$ & Melbourne & $\begin{array}{ll}\text { - } & \text { Architect } \\
\text { - } & \text { Playground users }\end{array}$ & $\begin{array}{l}\text { - Playground } \\
\text { designers, } \\
\text { Council } \\
\text { guidelines, } \\
\text { - Playground } \\
\text { supervisors }\end{array}$ & 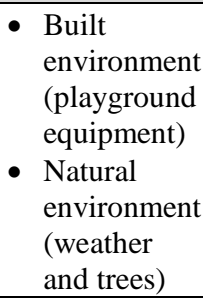 \\
\hline $\begin{array}{l}\text { Taekwondo } \\
\text { Club }\end{array}$ & Melbourne & $\begin{array}{l}\text { - Coach } \\
\text { - Athletes } \\
\text { - Researcher }\end{array}$ & $\begin{array}{l}\text { - } \text { Coaches, } \\
\text { Athletes } \\
\text { - Club fit-out } \\
\text { (interior } \\
\text { design) } \\
\text { - Event } \\
\text { organisers } \\
\text { - Event } \\
\text { personal } \\
\text { (e.g. } \\
\text { referees) }\end{array}$ & 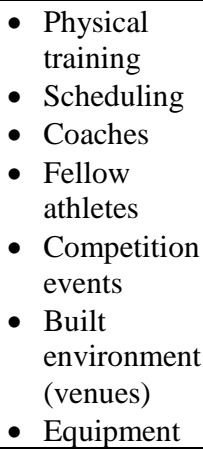 \\
\hline $\begin{array}{l}\text { Historic } \\
\text { Site }\end{array}$ & Tasmania & $\begin{array}{l}\text { - Tour operator } \\
\text { - Curator } \\
\text { - Visitors } \\
\text { - Researcher }\end{array}$ & $\begin{array}{l}\text { - Site/exhibit } \\
\text { ion } \\
\text { 'curators' } \\
\text { - Memorial } \\
\text { designer } \\
\text { - Boat } \\
\text { narrator } \\
\text { - Ghost tour } \\
\text { designer }\end{array}$ & 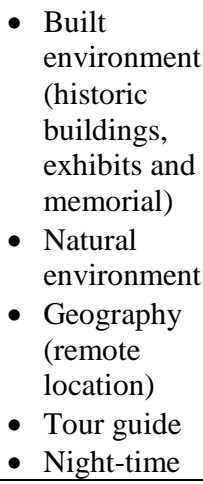 \\
\hline Museum & Sydney & $\begin{array}{ll}\text { - } & \text { Museum manager } \\
\text { - } & \text { Youth visitor } \\
\text { - } & \text { Researcher }\end{array}$ & $\begin{array}{l}\text { Exhibit } \\
\text { designer, } \\
\text { workshop } \\
\text { leader/ } \\
\text { designer }\end{array}$ & $\begin{array}{l}\text { - } \begin{array}{l}\text { Exhibit } \\
\text { (specimens) }\end{array} \\
\text { - Dissection } \\
\text { activity } \\
\text { - Built } \\
\text { environment }\end{array}$ \\
\hline $\begin{array}{l}\text { Sculpture } \\
\text { Walk }\end{array}$ & $\mathrm{NZ}$ & $\begin{array}{ll}\text { - } & \text { Visitors } \\
\text { - Artist/curator } \\
\text { - }\end{array}$ & $\begin{array}{l}\text { - Artists } \\
\text { - Curators }\end{array}$ & $\begin{array}{ll}\text { - } & \text { Art, } \\
\text { - Natural } \\
\text { environment } \\
\text { (landscape) } \\
\text { - Signage }\end{array}$ \\
\hline
\end{tabular}




\section{Method}

Hickey-Moody (2013a) argues that using affect as method offers "new mixtures of thought" and can "change research landscapes by shifting the registers on which particular issues or questions tend to be worked" (p. 85). Artistic research techniques such as the generation of photographic essays and soundscapes in response to the 'data encounter' provide aesthetically sensitive pathways for working with affect as method (Hickey-Moody, 2013a, p. 87) to create a research assemblage that in turn carries its own affective capacities. The exemplar $\mathrm{PhD}$ study combines art-based methods with more traditional qualitative methods such as documentary analysis and interviews as used in sensory ethnography (Pink, 2015) to achieve the ultimate goal of experimental yet robust research.

\section{IMPLICATIONS OF THIS RESEARCH FOR PRACTITIONERS}

With the introduction of social and emotional learning in Australian curriculums and OECD frameworks, research that accounts for the affective dimensions of learning spaces and their pedagogies is timely and relevant. The exemplar $\mathrm{PhD}$ research can be used to demonstrate the significance of learning space research that extends beyond psychological definitions of affect and dominant cognitivist and social constructivist understandings of pedagogy. Significantly it has the potential to show how manipulation of learning spaces can create pedagogic affect and how pedagogic affect transforms learning spaces. In practical terms there are implications for the likes of galleries, museums, sports clubs, theatre arts, and historical sites.

By identifying the inherent value of heterogeneous learning spaces as sites of affective pedagogical encounters such research will provide advocacy for programs that fall outside established grammars of schooling and curriculum. This will lend recognition and legitimacy to the pedagogies of heterogeneous learning spaces, promoting the development of their unique pedagogic potential to the full, without unnecessarily forcing school-based practices upon them. The exemplar $\mathrm{PhD}$ research can achieve this by establishing the characterisations of the dimensions of affective learning and the conditions required for affective pedagogic contexts to effectively operate - informing future development of 'scenes of pedagogical address.' Not only will this foster a broader view of pedagogical vernaculars and their potential, but it will also pave the way for invigorated relationships between schools and broadly conceived spaces of learning. 


\section{REFERENCES}

Alaimo, S., \& Hekman, S. J. (2008). Material feminisms. Bloomington: Indiana University Press.

Albrecht-Crane, C., \& Daryl Slack, J. (2003). Toward a pedagogy of affect. In J. Daryl Slack (Ed.), Animations of Deleuze and Guattari. New York: P. Lang.

Anderson, B., \& Harrison, P. (2012). The promise of non-representational theories. In P. D. Harrison \& B. D. Anderson (Eds.), Taking-Place [electronic resource]: Non-representational theories and geography. Farnham: Ashgate Publishing Ltd.

ATC21S. (2009-2012). Assessment \& Teaching of 21st Century Skills. Retrieved from http://www.atc21s.org

Baker, J. (2008). Beyond the rational museum: Toward a discourse of inclusion. Retrieved from http://dro.deakin.edu.au/eserv/DU:30048410/baker-beyondtherational-2008.pdf

Barad, K. M. (2007). Meeting the universe halfway: Quantum physics and the entanglement of matter and meaning. Durham: Duke University Press.

Bissell, D. (2012). Placing affective relations: Uncertain geographies of pain. In P. D. Harrison \& B. D. Anderson (Eds.), Taking-Place [electronic resource]: Non-representational theories and geography. Farnham: Ashgate Publishing Ltd.

Blackmore, J., Bateman, D., O’Mara, J., Loughlin, J., \& Aranda, G. (2010). The connections between learning spaces and learning outcomes: People and learning places? Retrieved from Learning Spaces website: http://www.learningspaces.edu.au/docs/learningspaces-literature-review.pdf

Bruce Mau Design., O'Donnell Wicklund Pigozzi and Peterson Architects Inc., \& VS Furniture. (2010). The third teacher: 79 ways you can use design to transform teaching \& learning. New York: Abrams.

Burke, C. (2008). 'Play in focus': Children's visual voice in participative research. In P. Thomson (Ed.), Doing visual research with children and young people. London: Routledge.

Byers, T., Imms, W. (2016). Evaluating the change in space in the primary years. In K. Fisher (Ed.), The translational design of schools: An evidence based approach to aligning pedagogy and learning environments in schools. Amsterdam, Netherlands: Sense Publishing.

Byers, T., Imms, W., \& Hartnell-Young, E. (2014). Making the case for space: The effect of learning spaces on teaching and learning. Curriculum and Teaching, 29(1), 5.

Cadman, L. (2009). Non-representational theory/non-representational geographiesInternational Encyclopedia of Human Geography (pp. 456-463): Elsevier Ltd. Retrieved from https://ezp.lib.unimelb.edu.au/login?url=https://search.ebscohost.com/login.aspx?direct=true $\& d b=e d$ selp\&AN=B9780080449104007173\&site=eds-live\&scope=site http://www.sciencedirect.com/science/article/pii/B9780080449104007173. doi:10.1016/B978008044910-4.00717-3

CERI. (2015). Innovative learning environments [Brochure]: OECD.

Clough, P. T., \& Halley, J. O. M. (2007). The affective turn: Theorizing the social. Durham: Duke University Press.

Coole, D. H., \& Frost, S. (Eds.). (2010). New materialisms: Ontology, agency, and politics. Durham [NC]; London: Duke University Press.

DEECD. (2009). Pedagogy and space: Transforming learning through innovation. Retrieved from http://www.education.vic.gov.au/researchinnovation/lpd/resources.htm

Deed, C., \& Lesko, T. (2015). 'Unwalling' the classroom: Teacher reaction and adaptation. Learning Environments Research, 18(2), 217-231. doi:10.1007/s10984-015-9181-6

Dovey, K., \& Fisher, K. (2014). Designing for adaptation: The school as socio-spatial assemblage. Journal of Architecture, 19(1), 43-63. doi:10.1080/13602365.2014.882376

Ellsworth, E. (2005). Places of learning [electronic resource]: Media, architecture, pedagogy Retrieved from cat00006a database

Farrelly, A., Forster, R., \& Smith, K. (2014). Building resilience in children and young people: A literature review for the Department of Education and Early Childhood Development (DEECD). Retrieved from http://www.education.vic.gov.au/about/department/Pages/resiliencelitreview.aspx.

Fenwick, T., Edwards, R., \& Sawchuk, P. (2011). Emerging approaches to educational research: Tracing the sociomaterial: Routledge.

Fisher, K. (2004). Revoicing classrooms: A spatial manifesto. FORUM: for promoting 3-19 comprehensive education, 46(1), 36-38. Retrieved from 
https://ezp.lib.unimelb.edu.au/login?url=https://search.ebscohost.com/login.aspx?direct=true\&db=er ic \&AN=EJ738542\&site $=$ eds-live \&scope $=$ site

http://www.wwwords.co.uk/forum/content/pdfs/46/issue46_1.asp

Fox, N. J., \& Alldred, P. (2015). New materialist social inquiry: Designs, methods and the researchassemblage. International journal of social research methodology, 18(4), 399-414. doi:10.1080/13645579.2014.921458

Gulson, K., \& Symes, C. (Eds.). (2007). Spatial theories of education: Policy and geography matters. Hoboken: Taylor \& Francis.

Harris, B. (2010). Reclaiming the radical legacy of Gestalt education in contemporary educational practice. British Gestalt Journal, 19(1), 19-25. Retrieved from https://ezp.lib.unimelb.edu.au/login?url=https://search.ebscohost.com/login.aspx?direct=true\&db=ed sbl\&AN=RN274229687\&site $=$ eds-live \&scope $=$ site

Hattie, J. (2008). Visible learning: a synthesis of over 800 meta-analyses relating to achievement. London; New York: Routledge.

Healy, S., Grant, G., Villafrance, E., \& Yang, P. (2015). Beyond the bounded notion of the classroom: A theoretical orientation for evaluating the geographies of new generation learning environments. Paper presented at the Terrains: Mapping learning environment evaluation across the design and education landscape, Singapore Theatre, Melbourne School of Design, University of Melbourne.

Hickey-Moody, A. (2013a). Affect as method: Feelings, aesthetics, and affective pedagogy. In R. Coleman \& J. Ringrose (Eds.), Deleuze and research methodologies. Edinburgh: Edinburgh University Press.

Hickey-Moody, A. (2013b). Youth, arts and education: Reassembling subjectivity through affect (First ed.). New York; London: Routledge.

Hickey-Moody, A., \& Crowley, V. (2010). Disability matters: Pedagogy, media and affect. Discourse: Studies in the Cultural Politics of Education, 31(4), 399-409. doi:10.1080/01596306.2010.504358

Ingold, T. (2011). Being alive: Essays on movement, knowledge and description. London; New York: Routledge.

Jackson, A. Y., \& Mazzei, L. A. (2012). Thinking with theory in qualitative research: Viewing data across multiple perspectives (First ed.). London: Routledge.

Kraftl, P. (2015). Geographies of alternative education: Diverse learning spaces for children and young people. Bristol: Policy Press.

Leander, K. M., Phillips, N. C., Taylor, K. H., Nespor, J., \& Lewis, C. (2010). The changing social spaces of learning: Mapping new mobilities. Review of Research in Education, 34, 329-394. Retrieved from https://ezp.lib.unimelb.edu.au/login?url=https://search.ebscohost.com/login.aspx?direct=true\&db=ed sjsr\&AN=edsjsr.40588181\&site=eds-live \&scope=site

Lefebvre, H. (1991). The production of space (D. Nicholson-Smith, Trans.). Oxford, UK: Blackwell Publishing.

Lenz Taguchi, H. (2011). Challenging the Reggio Emilia approach with relational materialist thinking and an ethics of potentialities. In R. House (Ed.), Too much, too soon? Early learning and the erosion of childhood. Stroud, Gloucestershire: Hawthorn Press.

Lenz Taguchi, H. (2012). A diffractive and Deleuzian approach to analysing interview data. Feminist Theory, 265. Retrieved from https://ezp.lib.unimelb.edu.au/login?url=https://search.ebscohost.com/login.aspx?direct=true\&db=ed sswe\&AN=edsswe.oai.DiVA.org.su.84897\&site=eds-live\&scope=site

Lenz-Taguchi, H. (2010). Going beyond the theory/practice divide in early childhood education: Introducing an intra-active pedagogy. Abingdon, Oxon: Routledge.

Lorimer, H. (2005). Cultural geography: The busyness of being 'more-than-representational'. Progress in Human Geography, 29(1), 83-94. doi:10.1191/0309132505ph531pr

McGregor, J. (2004a). Editorial. FORUM: for promoting 3-19 comprehensive education, 46(1), 2-5. Retrieved from https://ezp.lib.unimelb.edu.au/login?url=https://search.ebscohost.com/login.aspx?direct=true \&db=er ic $\& A N=E J 738537 \&$ site $=$ eds-live $\&$ scope $=$ site http://www.wwwords.co.uk/forum/content/pdfs/46/issue46_1.asp

McGregor, J. (2004b). Space, power and the classroom. FORUM: for promoting 3-19 comprehensive education, 46(1), 13-18. Retrieved from 
https://ezp.lib.unimelb.edu.au/login?url=https://search.ebscohost.com/login.aspx?direct=true\&db=er ic \&AN=EJ738537\&site $=$ eds-live \&scope $=$ site

http://www.wwwords.co.uk/forum/content/pdfs/46/issue46_1.asp

McLeod, J. (2014). Space, place and purpose in designing Australian schools. History of Education Review, 43(2), 1-6. Retrieved from

https://ezp.lib.unimelb.edu.au/login?url=https://search.ebscohost.com/login.aspx?direct=true\&db=eh h\&AN=99990636\&site=eds-live \&scope $=$ site

Mulcahy, D. (2012). Affective assemblages: Body matters in the pedagogic practices of contemporary school classrooms. Pedagogy, Culture and Society, 20(1), 9-27.

Mulcahy, D. (in press). 'Sticky' learning: Assembling bodies, objects and affects at the museum and beyond. In J. Coffey, S. Budgeon, \& H. Cahill (Eds.), Learning bodies: The body in youth and childhood studies. Dordrecht: Springer.

Mulcahy, D., Cleveland, B., \& Aberton, H. (2015). Learning spaces and pedagogic change: Envisioned, enacted and experienced. Pedagogy, Culture \& Society, 23(4), 575-595. doi:10.1080/14681366.2015.1055128

OECD. (2008). 21st Century learning: Research, innovation and policy. Paper presented at the OECD/CERI International Conference. http://www.oecd.org/site/educeri21st/40554299.pdf

OECD. (2013). Innovative learning environments. Retrieved from http://www.oecd.org/edu/ceri/innovativelearningenvironmentspublication.htm

Pink, S. (2015). Doing sensory ethnography (2nd ed.). Los Angeles, CA: Sage.

Resnick, L. B., Spillane, J. P., Goldman, P., \& Rangel, E. S. (2010). Implementing innovation: From visionary models to everyday practice. In H. Dumont, D. Istance, \& F. Benavides (Eds.), The nature of learning: Using research to inspire practice (pp. 285-315). Paris and Washington, D.C: OECD.

Ross, M., Hancock, R., \& Bagnall, K. (2004). Pedagogy in a public space: Children and adults learning together at Tate Modern. Forum for Promoting 3-19 Comprehensive Education(1). Retrieved from https://ezp.lib.unimelb.edu.au/login?url=https://search.ebscohost.com/login.aspx?direct=true\&db=ed sgao\&AN=edsgcl.249495923\&site=eds-live\&scope $=$ site

Saltmarsh, S., Chapman, A., Campbell, M., \& Drew, C. (2015). Putting "structure within the space": Spatially un/responsive pedagogic practices in open-plan learning environments. Educational Review, 67(3), 315-327. doi:10.1080/00131911.2014.924482

Skattebol, J. (2010). Affect: A tool to support pedagogical change. Discourse: Studies in the Cultural Politics of Education, 31(1), 75-91. Retrieved from https://ezp.lib.unimelb.edu.au/login?url=https://search.ebscohost.com/login.aspx?direct=true \&db=er ic \&AN=EJ881194\&site=eds-live \&scope=site http://www.informaworld.com/openurl?genre=article\&id=doi:10.1080/01596300903465435

Soja, E. W. (1996). Thirdspace: Journeys to Los Angeles and other real-and-imagined places. Cambridge, Mass: Blackwell.

Tyack, D., \& Tobin, W. (1994). The 'grammar' of schooling: Why has it been so hard to change? American Educational Research Journal(3), 453. Retrieved from https://ezp.lib.unimelb.edu.au/login?url=https://search.ebscohost.com/login.aspx?direct=true\&db=ed sjsr\&AN=edsjsr. $1163222 \&$ site $=$ eds-live \&scope $=$ site

Vannini, P. (Ed.) (2015). Non-representational methodologies: Re-envisioning research. New York: Routledge.

VCAA. (n.d.). Victorian curriculum: personal and social capability. Retrieved from http://victoriancurriculum.vcaa.vic.edu.au/personal-and-social-capability/introduction/rationale-andaims

Walshaw, M., \& Brown, T. (2012). Affective productions of mathematical experience. Educational Studies in Mathematics (1-2), 185.

Watkins, M. (2006). Pedagogic affect/effect: Embodying a desire to learn. Pedagogies, 1(4), 269-282. doi:10.1080/15544800701341533

Watkins, M. (2011). Teachers' tears and the affective geography of the classroom. Emotion, Space and Society, 4, 137-143. doi:10.1016/j.emospa.2010.03.001

Woolner, P., Clark, J., Laing, K., Thomas, U., \& Tiplady, L. (2014). A school tries to change: How leaders and teachers understand changes to space and practices in a UK secondary school. Improving Schools, 17(2), 148-162. Retrieved from 
https://ezp.lib.unimelb.edu.au/login?url=https://search.ebscohost.com/login.aspx?direct=true $\& d b=e r$ ic \&AN=EJ1039873\&site=eds-live \&scope $=$ site

http://dx.doi.org/10.1177/1365480214537931

Yin, R. K. (2014). Case study research: Design and methods (5th ed.). Los Angeles: Sage.

Youdell, D., \& Armstrong, F. (2011). A politics beyond subjects: The affective choreographies and smooth spaces of schooling. Emotion, Space and Society, 4, 144-150. doi:10.1016/j.emospa.2011.01.002

Zembylas, M. (2007a). Risks and pleasures: a Deleuzo-Guattarian pedagogy of desire in education. British Educational Research Journal, 33(3), 331-347. doi:10.1080/01411920701243602

Zembylas, M. (2007b). The "specters" of bodies and affects in the classroom: A rhizo-ethological approach. Pedagogy, Culture and Society, 15(1), 19-35. Retrieved from

https://ezp.lib.unimelb.edu.au/login?url=https://search.ebscohost.com/login.aspx?direct=true \&db=er ic \&AN=EJ937962\&site=eds-live \&scope=site

http://www.informaworld.com/openurl?genre=article\&id=doi:10.1080/14681360601162030

Sarah Healy,

Melbourne Graduate School of Education

The University of Melbourne 